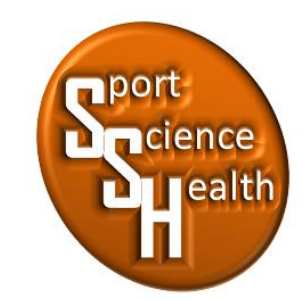

ISSN 2715-3886

\title{
Upaya Peningkatan Penguasaan Teknik Dasar dalam Bermain Sepakbola dengan Metode Peragaan Pada Siswa Kelas V (Lima) SD
}

\author{
Ngasto Diharjo ${ }^{1 *}$ \\ ${ }^{1}$ SD Negeri Pagentan 02 Singosari, Jl. Kartanegara Desa No. 99, RT.04/RW.03, Candirenggo, Pagentan, \\ Kec. Singosari, Malang, Jawa Timur 65153, Indonesia \\ *Penulis koresponden: ngasto.diharjo@gmail.com
}

\begin{abstract}
The objectives of this study are (a) Knowing the improvement of basic mastery achievement in the game of football after applying the demonstration method, (b) Knowing the motivation to learn basic techniques in playing football in Class V (Five) Pagentan State Elementary School 02 Singosari 2017/2018 Academic Year after the demonstration method is applied. This study uses two rounds of action research. Each round consists of two shelves: design, activity and observation. Reflection and refission The purpose of this study is students of class V (five) SD Negeri Pagentan 02 Singosari 2017/2018 Academic Year from the data obtained in the form of test results, observation sheets of teaching and learning activities. From the analysis results obtained from student learning outcomes increased from cycle I to II, namely, cycle I (61.54\%), cycle II (89.74\%) for the psychomotor domain, cycle I (84.62\%). Cycle II (100\%) for the active domain. The conclusion of this study is a positive method of student motivation in class V (five) SD Negeri Pagentan 02 Singosari 2017/2018 Academic Year and learning models can be used as an alternative to physical education.
\end{abstract}

Keyword: basic techniques, football, modeling methods

\begin{abstract}
Abstrak: Tujuan dari penelitian ini adalah (a) Mengetahui peningkatan prestasi penguasaan dasar dalam permainan sepakbola setelah menerapkan metode peragaan, (b) Mengetahui motivasi belajar teknik dasar dalam bermain sepak bola pada siswa Kelas V (Lima) SD Negeri Pagentan 02 Singosari Tahun Pelajaran 2017/2018 setelah diterapkan metode peragaan. Penelitian ini menggunakan penelitian tindakan (action research) sebanyak dua putaran. Setiap putaran terdiri dari dua rak yaitu: merancang, kegiatan dan pengamatan. Refleksi dan refisi Tujuan penelitian ini adalah siswa kelas V (lima) SD Negeri Pagentan 02 Singosari Tahun Pelajaran 2017/2018 dari data yang diperoleh berupa hasil tes, lembar pengamatan kegiatan belajar mengajar. Dari hasil analisis diperoleh dari hasil belajar siswa meningkat dari siklus I hingga II yaitu, siklus I (61,54\%), siklus II (89,74\%) untuk ranah psikomotro, siklus I (84,62\%). Siklus II (100\%) untuk ranah aktif. Simpulan dari penelitian ini adalah metode positif terhadap motivasi belajar siswa kelas V (lima) SD Negeri Pagentan 02 Singosari Tahun Pelajaran 2017/2018 dan model pembejalaran dapat digunakan sebagai salah satu alternatif pendidikan jasmani.
\end{abstract}

Kata kunci: teknik dasar, sepakbola, metode peragaan

\section{PENDAHULUAN}

Sepakbola menjadi salah satu olahraga yang sangat digemari dan sudah dikenal di seluruh lapisan masyarakat. Hal ini terbukti dengan banyaknya sekolah-sekolah sepakbola dan klub-klub sepakbola di 
berbagai daerah. Sepakbola berkembang dengan pesat di kalangan masyarakat, karena permainan ini dapat dimainkan oleh laki- laki dan perempuan, anak-anak, dewasa, serta orang tua (Sucipto, dkk, 1999/2000:7).

Sepakbola merupakan permainan beregu, masing-masing regu terdiri dari sebelas pemain, dan salah satunya penjaga gawang. Permainan ini hampir seluruhnya dimainkan dengan menggunakan tungkai kecuali penjaga gawang yang diperbolehkan menggunakan lengannya didaerah pinaltinya sendiri. Dalam perkembangannya permainan ini dapat dimainkan di luar lapangan (outdoor) dan di dalam ruangan tertutup (indoor).

Tujuan utama dalam permainan sepakbola adalah pemain memasukkan bola sebanyak-banyaknya ke gawang lawannya dan berusaha menjaga gawangnya agar tidak kemasukan. Suatu regu dinyatakan menang apabila regu tersebut dapat memasukkan bola lebih banyak ke gawang lawan.

Sepakbola adalah permainan yang sederhana. Meskipun demikian ada beberapa aspek yang perlu diberikan perhatian secara khusus. Diantaranya adalah aspek teknik, aspek fisik, dan taktik atau strategi. Beberapa aspek tersebut tidak dapat dipisahkan satu sama lain. Setiap pemain sepakbola diharapkan memiliki teknik yang bagus serta fisik yang prima agar dapat menjalankan taktik dan strategi dari seorang pelatih.

\section{METODE}

Penelitian ini merupakan penelitian tindakan (action research) karena penelitian dilakukan untuk memecahkan masalah pembelajaran di kelas. Penelitian ini juga termasuk penelitian dskriptif, sebab menggambarkan bagaimana suatu teknik pembelajaran diterapkan dan bagaimana hasil yang diinginkan dapat dicapai.

Menurut oja dan sumarjan (dalam titik sugiarti, 1997:8) ada 4 macam bentuk penelitian tindakan, yaitu (1) penelitian tindakan guru sebagai peneliti, (2) penelitian tindakan kolaboratif, (3) penelitian tindakan simulatif terinteratif dan (4) penelitian tindakana social eksperimental.

Dalam penelitian tindakan ini menggunakan bentuk penelitian kolaboratif dengan guru mata diklat dan di dalam proses belajar mengajar dikelas yang bertinak sebagai pengajar adalah guru mata diklat sedangkan peneiti bertindak sebagai pengamat, penanggung jawab penuh penelitian tindakan adalah pengamat (peneliti). Tujuan utama dari penelitian tindakan ini adalah meningkatkan hasil pembelajaran di kelas dimana peneliti secara penuh terlibat dala penelitian mulai dari perencanaan, tindakan, pengamatan dan refleksi.

\section{Tahap Perencanaan}

Penelitian ini menggunakan penelitian tindakan kelas (PTK). Menurut tim pelatih proyek PGSM, PK adalah suatu bentuk kajian yang bersifat reflektif oleh pelaku tindakan yang dilakukan untuk meningkatkan kemantapan rasional dari tindakan mereka dalam melaksanakan tugas, memperdalam pemahaman terhadap tindakan-tindakan yang dilakukan itu, serta memperbaiki kondisi dimana praktek pembelajaran tersebut dilakukan (dalam Mukhlis, 2003:3)

Sedangkan menurut mukhlis (2003:5) ptk adalah suatu bentuk kajian yang bersifat sistematis reflektif oleh pelaku tindakan untuk memperbaiki kondisi pembelajaran yan dilakukan.

Adapun Tujuan Utama Dari Ptk Adalah Untuk Memperbaiki / Meningkatkan Praktek Pembelajaran Secara Berkesinambungan, Sedangkan Tujuan Penyertaannnya Adalah Menumbuhkan Budaya Meneliti Dikalangan Guru(Mukhlis, 2003:5).

PTK terdiri atas empat tahap, yaitu planning (rencana), action (tindakan), observasi (pengamatan) dan reflection (refleksi).

Instrument Yang Digunakan Dalam Penelitian Ini Terdiri Dari: (1) Silabus, (2) Rpp, (3) Lembar Observasi Kegiatan Belajar Mengajar, (4) Angkat Motivasi Terhadap Metode Peragaan, (5) Tes Praktek, (6) Lembar Observasi Penilaian Kinerja Siswa Ranah Psikomotor, (7) Lembar Observasi Penilaian Kinreja Siswa Ranah Afektif

\section{Tahap Tindakan}

\section{Metode Pengumpulan Data}

Data-Data Yang Diperlukan Dalam Penelitian Ini Diperoleh Melalui Observasi Pengolahan Metode Peragaan, Observasi Aktivitas Siswa Dan Guru Angket Motivasi Siswa Dan Tes Praktek 
Pada tahap ini peneliti mempersiapkan pembelajaran yang terdiri dari rencana pelajaran 1, soal tes formatif 1 dan alat-alat pengajaran yang mendukung. Selain itu juga dipersiapkan lembar observasi pengelolahan pembelajaran metode demostrasi dan lembar observasi aktivitas siswa.

Pada akhir proses belajar mengajar siswa diberi tes formatif i dengan tujuan untuk mengetahui keberhasin siswa dalam proses belajar mengajar yang telah dilakukan. Adapun data hasil penelitian pada siklus i adalah sebagai berikut: bahwa aktivitas guru yang paling dominan pada siklus i adalah menjelaskan materi yang sulit, membimbing dan mengamati siswa dalam menemukan konsep yaitu $21,7 \%$. Aktivitas lain yang persentasenya cukup besar adalah memberi umpan balik/evaluasi/tanya jawab, menjelaskan materi yang sulit dan membimbing siswa merangkum pelajaran yaitu masing-masing sebesar $18,3 \%$ dan $13,3 \%$. Sedangkan aktivitas siswa yang paling dominan adalah mengerjakan/memperhatikan penjelasan guru yaitu $22,5 \%$. Aktivitas lain yang persentasenya cukup besar adalah bekerja dengan sesama anggota kelompok, diskusi antar siswa dengan guru, dan membaca bukup yaitu masing-masing 18,8\% dan 11,5\%.

Berikutnya adalah rekapitulasi hasil tes formatif siswa seperti terlihat pada tabel berikut ini:

Tabel 1. Rekapitulasi Hasil Tes Formatif Siswa Pada Siklus I

\begin{tabular}{llr}
\hline No & Uraian & Hasil Siklus I \\
\hline 1 & Nilai rata-rata tes formatif & 76,15 \\
\hline 2 & Jumlah siswa yang tuntas belajar & 24 \\
\hline 3 & Per Persentase ketuntasan belajar & 61,54 \\
\hline
\end{tabular}

Sedangkan untuk aktivitas siswa yang paling diminan pada siklus II adalah praktik menggunakan alat yaitu (21\%). Jika dibandingkan dengan siklus I, aktivitas ini mengalami peningkatan. aktivitas siswa yang mengalami penurunan adalah mendengarkan / memperhatikan penjelasan guru (17,9\%). Diskusi antar siswa / antara siswa dengan guru $(13,8 \%)$, mempraktekkan yang relavan dengan KBM $(7,7 \%)$ dan merangkum pembelajaran $(6,7 \%)$. Adapun aktivitas siswa yang mengalami peningkatan aalah memperhatikan peragaan $(12,1 \%)$ menyajikan hasil pembelajaran (4,6\%), menanggapi / mengajukan pertanyaan / ide $(5,4 \%)$ dan berlatih bersama siswa lain (10,8\%).

Analisis data penelitian Siklus I.

\section{Ranah Psikomotor}

Siswa yang mendapat nilai 60 tidak ada. Siswa yang mendapat nilai 70 sebanyak 15 (38,46\%). Siswa yang mendapat nilai 80 sebanyak 24 (61,54\%). Berarti siswa yang mendapat nilai diatas 70 sebanyak 61, 54\%, secara klasikal termasuk kategori belum tuntas.

\section{Ranah Afektif}

Siswa yang mendapat nilai C sebanyak 6 (15,38\%), Siswa yang mendapat nilai B sebanyak $26(66,6 \%)$. Siswa yang mendapat nilai A sebanyak 7 (17,95\%). Berarti siswa yang mendapat nilai diatas C sebanyak $84,62 \%$, secara klasikal termasuk kategori tuntas.

Hasil tes praktik siswa terlihat pada tabel berikut

Tabel 4.6 Rekapitulasi Hasil Tes Formatif Siswa Pada Siklus II

\begin{tabular}{llr}
\hline No & Uraian & Hasil Siklus II \\
\hline 1 & Nilai rata-rata tes formatif & 81,79 \\
\hline 2 & Jumlah siswa yang tuntas belajar & 35 \\
\hline 3 & Per Persentase ketuntasan belajar & 89,74 \\
\hline
\end{tabular}

Berdasarkan tabel di atas diperoleh nilai rata-rata tes praktek sebesar 81,79 dan dari 39 siswa yang telah tuntas sebanyak 35 siswa 4 siswa belum mencapai ketuntasan belajar. Maka secara klasikal ketuntasan belajar yang telah tercapai sebesar $89,74 \%$ (termasuk kategori tuntas). Hasil pada siklus II ini mengalami 
peningkatan lebih baik dari siklus I. Adanya peningkatan hasil belajar pada siklus II ini dipengaruhi oleh adanya peningkatan kemampuan guru dalam menerapkan pembelajaran metode demonstrasi sehingga siswa menjadi lebih terbiasa dengan pembelajaran seperti ini sehingga siswa lebih mudah dala memahami materi yang telah diberikan

Analisis data penelitian Siklus II

\section{Ranah Psikomotor}

Siswa yang mendapat nilai 60 tidak ada. Siswa yang mendapat nilai 70 sebanyak 4 (10,36\%). Siswa yang mendapat nilai 80 sebanyak 24 (61,53\%). Siswa yang mendapat nilai 90 sebanyak $11(28,21 \%)$. Berarti siswa yang mendapat nilai diatas 70 sebanyak $89,74 \%$, secara klasikal termasuk kategori tuntas.

\section{Ranah Afektif}

Siswa yang mendapat nilai $C$ tidak ada. Siswa yang mendapat nilai B sebanyak 13 (33,33\%). Siswa yang mendapat nilai A sebanyak 26 (66,67\%). Berarti siswa yang mendapat nilai diatas C mencapai $100 \%$ secara klasikal termasuk kategori tuntas

\section{PEMBAHASAN}

\section{Ketuntasan Hasil belajar siswa}

Melalui hasil penelitian ini menunjukkan bahwa pembelajaran pertemuan terbimbing memiliki dampak positif dalam meningkatkan prestasi belajar siswa. Hal ini dapat dilihat dari semakin mantapnya pemahaman siswa terhadap materi yang disampaikan guru (ketuntasan belajar meningkat dari siklus I, dan II) untuk ranah psikomotor yaitu $61,54 \%, 84,62 \%$ dan $100 \%$. pada siklus II ketuntasan belajar siswa secara klasikal telah tercapai.

\section{Kemampuan Guru dalam Mengelola Pembelajaran}

Berdasarkan analisis data, diperoleh aktivitas siswa dalam proses belajar mengajar dengan menerapkan metode demonstrasi dalam setiap siklus mengalami peningkatan. Hal ini berdampak positif terhadap prestasi belajar siswa yaitu dapat ditunjukkan dengan meningkatnya nilai rata-rata siswa pada setiap siklus yang terus mengalami peningkatan.

\section{Aktivitas Siswa dalam Pembelajaran}

Berdasarkan analisis data, diperoleh aktivitas siswa dalam proses pembelajaran dengan model pembelajaran metode demonstrasi paling dominan adalah belajar dengan sesama anggota kelompok, mendengarkan/memperhatikan penjelasan guru dan diskusi antara siswa/antara siswa dengan guru. Jadi dapat dikatakan bahwa aktivitas siswa dapat dikategorikan aktif.

Sedangkan untuk aktivitas guru selama pembelajaran telah melaksanakan langkah-langkah metode demonstrasi dengan baik. Hal ini terlihat dari aktivitas guru yang muncul di antaranya aktivitas membimbing dan mengamati siswa dalam mempraktikkan hasil pembelajaran, menjelaskan/melatih menggunakan alat, memberi umpan balik dalam prosentase untuk aktivitas di atas cukup besar.

\section{Tanggapan siswa terhadap Model pembelajaran metode demonstrasi}

Berdasarkan analisis angket siswa dapat diketahui bahwa tanggapan siswa termasuk positif. Ini ditunjukkan dengan rata-rata jawaban siswa yang menyatakan bahwa siswa tertarik dan berminat dengan model pembelajaran model dmonstrasi. Hal ini menunjukkan bahwa siswa memberikan respopn positif terhadap model pembelajaran metode demonstrasi, sehingga siswa menjadi termotivasi untuk belajar lebih giat. Jadi dapat disimpulkan bahwa dengan diterapkannya metode demonstrasi dapat meningkatkan motivasi belajar siswa. 


\section{KESIMPULAN}

Dari hasil kegiatan pembelajaran yang telah dilakukan selama tiga siklus dan berdasarkan seluruh pembahaan serta analisis yang telah dilakukan dapa disimpulkan sebagai berikut. Pembelajaran dengan metode pembelajaran metode demonstrasi memiliki dampak positif dalam meningkatkan prestasi belajar siswa yang ditandai dengan peningkatan ketuntasan belajar siswa dalam setiap siklus, yaitu siklus I $(61,54 \%)$, siklus II $(89,74 \%)$, sedangkan untuk ranah afektif yaitu siklus I (84,62\%), siklus II (100\%).

\section{DAFTAR PUSTAKA}

Arikunto, Suharsimi, 2002. Prosedur Penelitian Suatu Pendekatan Praktik. Jakarta PT. Rineksa Cipta Bachrie, Eddy, dkk. 1982. Buku Kerja Pelatih Sepakbola Remajai. Bandung; Binacipta Betty, C. Eric. 1987. Latihan Sepakbola Metode Baru Pertahanan. Bandung; Pioner Jaya Coever, Weil. 1982; Sepakbola Pembinaan Pemain Ideal. Jakarta; PT Gramedia.

Engkos S.R. 1994. Penjaskes. Jakarta; Erlangga

Remmy, Muchtar. 1992. Olahraga Pilihan Sepakbola, Jakarta; Depdikbud Dirjen Dikti

Roji. 1996. Penjaskes 3, Jakarta; Intan Parawara

Sajono, 1986. Pembinaan dan Kondisi fisik, Jakarta: Depdikbud Dirjen Dikti

Slamet, S.R. 1994.Penjaskes 3. Jakarta; Tiga Serangkai

Sneyer, J. 1988. Sepakbola Latihan dan Strategi, Jakarta; PT. Rosda Karya

Suharno. 1986, IImu Kepelatihan Olahraga Yogyakarta; IKIP Yogyakarta.

Syafi'I, Imam, 1999, Sepakbola Dasar. Surabaya; UM Press IKIP Surabaya

Syarifuddin, Aib. 1997, Penjaskes 1,2,3, Jakarta; PT. Gramedia Widiasmara Indonesia 